\title{
NEUROPEDAGOGIKA I EDUKACJA ALTERNATYWNA W OŚWIACIE XXI WIEKU
}

\begin{abstract}
Streszczenie: $\mathrm{W}$ artykule podjęto próbę nakreślenia podobieństw i różnic między neuropedagogiką a edukacją alternatywną jako koncepcjami, które stanowią współczesną odpowiedź na niepowodzenia obecnego systemu oświaty. Chwalone przez jednych, są intensywnie krytykowane przez innych. Dla jednych są rozwiązaniem idealnym, które wspiera rozwój dzieci, dla których nie ma miejsca w tradycyjnej szkole, dla innych - sposobem na dostatnie życie i źródłem dochodu. Niezależnie od oceny, warto przyjrzeć się bliżej ich źródłom, proponowanym oryginalnym rozwiązaniom oraz wpływowi na tradycyjny system oświaty.
\end{abstract}

Słowa kluczowe: neuropedagogika, edukacja alternatywna, tradycyjna szkoła

Kryzys systemu edukacji był od wieków motorem do poszukiwań nowych rozwiązań. Dotyczyły one pewnych koncepcji rozumienia procesu edukacji, ale także nowych sposobów definiowania przyczyn niepowodzeń. Z tej perspektywy nie dziwi rozwój zarówno edukacji alternatywnej, ale także neuropedagogiki. Znamienny jest fakt, że oba te pojęcia kształtowały się mniej więcej w tym samym czasie i w bliskich sobie ośrodkach naukowych. Warto przyjrzeć im się bliżej w świetle narastającego dziś kryzysu edukacji.

\section{EDUKACJA ALTERNATYWNA - SPOSÓB NA NIEPOWODZENIA TRADYCYJNEJ SZKOŁY}

Szkoły alternatywne zaczęły powstawać jako protest wobec powszechnej wówczas szkoły tradycyjnej, opartej na założeniach Herbarta. W latach 60. XX wieku radykalni krytycy szkoły tradycyjnej, zwani descholaryzatorami, uznali szkołę 
za instytucję anachroniczną i domagali się jej zlikwidowania lub przynajmniej zastąpienia przez alternatywne instytucje edukacyjne. Szkole tradycyjne przypisywano bowiem cechy takie jak: autorytaryzm, addytywizm i uniformizm programowy, metodyczny schematyzm, przekazywanie uczniom gotowej wiedzy do zapamiętania, a następnie do reprodukcji itd., podczas gdy jej antagonistyczne odpowiedniki (szkoły alternatywne) charakteryzowano przykładowo jako przystosowujące uczniów do samodzielnego myślenia i działania oraz łączenia teorii z praktyką itd. (Kupisiewicz 2010, s. 24).

W rezultacie tej krytyki powstały - najpierw w USA, a później w innych krajach - liczne szkoły alternatywne, np. „szkoły wolne” (free schools), „akademie uliczne” (street academies), „otwarte klasy” (open classrooms), „szkoły bez ścian” (schools without walls) itp. Pojęcie alternatywności dotyczyło wówczas głównie struktury oraz form organizacyjnych zinstytucjonalizowanego nauczania zarówno w szkolnictwie prywatnym, jak i - nieco później - publicznym (Husén, Postlethwaite 1985, s. 256).

Niemiecki pedagog G. Brinkmann do charakterystycznych cech nowopowstających szkół zaliczył:

1) Analizowanie celów i treści nauczania nie tyle z punktu widzenia potrzeb społecznych, ile pod kątem zainteresowań oraz potrzeb poznawczych uczniów;

2) Odrzucenie tzw. szkoły nauczającej (Lernschule), w której się tylko naucza, na rzecz szkoły wychowującej, która kształtuje charakter, poglądy, kryteria oceny różnych wartości itp.;

3) Położenie nacisku na respektowanie takich zasad pracy dydaktycznowychowawczej jak: zasada samodzielności uczniów, łączenia teorii z praktyką w nauczaniu, wzbogacania nauki szkolnej o elementy gier i zabaw (przede wszystkim w nauczaniu początkowym), a ponadto zasada całościowego traktowania osobowości każdego ucznia, w myśl której równie ważny jest jego rozwój umysłowy, jak fizyczny, emocjonalny i wolicjonalny (Brinkmann 1974, s. 77).

Z kolei Cz. Kupisiewicz zwrócił uwagę, że szkoła - jako najważniejsza instytucja oświatowa współczesnego społeczeństwa - jest potrzebna, a nawet „nieunikniona”. Musi to być jednak szkoła różniąca się pod wieloma względami od szkoły tradycyjnej. Powinna być otwarta na otoczenie oraz na postęp, który pobudza uczniów do samodzielnego myślenia i działania, do samorzutnej aktywności poznawczej. Szkoła musi także akceptować twórcze rozwiązania, które wywołują zainteresowanie uczniów, stymulują grupowe formy pracy umysłowej i manualnej, zapewniają szkole możliwości samofinansowania swoich potrzeb, m.in. poprzez łączenie nauki szkolnej z pracą uczniów w szkolnych warsztatach. Nowa szkoła 
- a taką jest szkoła alternatywna - powinna unikać błędów typowych dla szkoły tradycyjnej, a w szczególności:

- tworzenia klas z uczniów tego samego rocznika, często przecież różnych pod względem zdolności, zainteresowań, aspiracji edukacyjnych itp.;

- mnożenia przedmiotów nauki szkolnej bez względu na bieżące i dalekosiężne potrzeby poznawcze i zawodowe uczniów;

- uśredniania stopnia trudności realizowanych treści programowych, tempa uczenia się oraz czasu przeznaczonego na opanowanie określonych zagadnień;

- oceniania postępów uczniów w nauce w sposób faworyzujący kontrolę wiadomości, a prawie nie odnoszący się do nabywania umiejętności;

- stosowania przede wszystkim podających metod nauczania, w których uczeń jest biernym odbiorcą;

- ograniczania uczniom szerokiego i bezpośredniego kontaktu z przyrodą, życiem społecznym i kulturalnym oraz różnymi rodzajami produkcji i usług oraz zaznajamiania ich ze współczesnymi problemami globalnymi (Kupisiewicz 2010, s. 23).

W oparciu o powyższe można podsumować, że idea szkoły alternatywnej definiowana były w dwojaki sposób. Pierwszy z nich zaproponował B. Śliwierski, który uznał, że „szkoła alternatywna to rodzaj placówki oświatowej, zorganizowanej według odmiennych projektów edukacyjnych, stanowiących alternatywę wobec koncepcji realizowanych w szkołach prowadzonych przez organy administracji państwowej bądź gminnej. Do szkół alternatywnych zalicza się m.in. wolne szkoły typu Waldorf, szkoły odwołujące się do systemu pedagogicznego M. Montessori czy C. Freineta, a także część szkół prowadzonych przez stowarzyszenia społeczne bądź religijne" (Milerski, Śliwerski 2000, s. 13). Cytowany autor podkreśla także krytyczne podłoże inicjatyw alternatywnych w edukacji, będące warunkiem koniecznym każdego alternatywnego działania. Pojęcia „alternatywność” można zatem w edukacji używać w odniesieniu do szkół lub działań istniejących poza dominującym, standardowym, konwencjonalnym systemem kształcenia. Mogą one ponadto:

a) w całości lub w części inspirować się autorskimi programami pedagogicznymi szkół tzw. „nowego wychowania” z początku XX wieku;

b) wzorować się na szkołach „alternatywnych” typu open schools z lat 60 . $\mathrm{XX}$ wieku;

c) realizować innego rodzaju odmienne, specyficzne działania edukacyjne, determinowane namysłem krytycznym wobec istniejących w danym czasie rozwiązań edukacyjnych (Milerski, Śliwerski 2000, s. 13).

Inne podejście prezentuje Cz. Kupisiewicz. Wskazał on, że „szkoła alternatywna, w znaczeniu ogólnym, jest placówką oświatowo-wychowawczą, która w pełnym 
lub ograniczonym zakresie - stosownie do pełnej lub ograniczonej interpretacji zakresu terminu „alternatywność” - usiłuje zastąpić transmisyjno-reproduktywną doktrynę kształcenia, typową dla szkoły tradycyjnej, doktryną generatywną" (Kupisiewicz 2010, s. 22). Pedagog proponuje, by nazwę „alternatywne” odnieść raczej do szkół XX wieku, tj. amerykańskich tzw. open schools, duńskich e-erskole oraz szkół ówczesnej RFN pracujących według założeń R. Steinera, M. Montessori czy planu jenajskiego P. Petersena (Kupisiewicz 2006, s. 88-99). W ujęciu Cz. Kupisiewicza „alternatywność w edukacji” nie powinna być ograniczana wyłącznie do kategorii całościowych systemów pedagogicznych funkcjonujących w szkołach autorskich, lecz obejmować także częściowe lub niepełne ujęcia alternatywne, które dotyczą tylko pojedynczych składników procesu edukacji. W związku z tym alternatywność szkół może być całkowita lub częściowa (Kupisiewicz 2006, s. 85). Jako przykład Kupisiewicz podaje wykorzystanie w szkole technik Freineta czy metod stosowanych do doskonalenia wrażliwości zmysłów u dzieci w systemie Montessori. Można więc stwierdzić, iż „alternatywność” w takim ujęciu odnosi się zarówno do całościowych systemów pedagogicznych funkcjonujących w szkołach autorskich, jak i do pojedynczych działań edukacyjnych w szkołach różnego typu. Alternatywność to zatem przede wszystkim odmienność od szkoły tradycyjnej.

Niezależnie od sposobu definiowania, szkoła alternatywna przyczyniła się do popularyzacji przekonania, że:

a) o kształcie teleologicznym, programowym i metodyczno-medialnym przyszłej szkoły będą decydować przede wszystkich różnice między uczniami;

b) dominujący w szkole tradycyjnej układ „bierny uczeń - aktywny nauczyciel" ustąpi miejsca układowi, w którym uczeń stanie się podmiotem kształcenia, a tym samym aktywnym uczestnikiem tego procesu;

c) szkoła jako instytucja wymagająca ustawicznego ulepszania oraz przystosowywania do zmieniających się szybko warunków życia musi być wspierana przez lokalne środowisko;

d) W miejsce dotychczasowego systemu zinstytucjonalizowanej edukacji, zmonopolizowanego przez szkołę tradycyjną, zostanie zbudowany system „zintegrowany”, w którym istotne miejsce będzie zajmować szkoła alternatywna (Kupisiewicz 2013).

\section{NEUROPEDAGOGIKA A TRADYCYJNA EDUKACJA}

Pierwsze próby łączenia nauki z czynnikami biologicznymi podjął w 1869 roku w formie dyskusji F. Galton (brytyjski podróżnik, przyrodnik, antropolog) zastanawiając się, co ma silniejszy wpływ na proces uczenia się: natura czy wychow- 
anie. Jednakże dopiero w latach $70 . \mathrm{XX}$ wieku nastąpił wzrost zainteresowania w zakresie w/w badań, co sprawiło, że przestały być one jedynie częścią innych szeroko zakrojonych działań. Pojawiła się bowiem nowa dyscyplina naukowa: neuropsychologia edukacyjna. Stanowiła ona pole interdyscyplinarnych badań z zakresu popularnej i ugruntowanej w tym czasie neuropsychologii oraz procesu edukacji. W 1978 roku ukazały się książki z omawianego zakresu: "Brain Research and Learning" (Claycomb 1978) i "Education and the brain” (Chall, Mirsky 1978). Ich autorzy skupiali się jednakże wyłącznie na badaniu procesu uczenia się (learning), pomijając nauczanie (teaching).

W latach 80 . XX wieku nastąpił intensywny rozwój metod obrazowania mózgu (rezonans magnetyczny, funkcjonalny rezonans magnetyczny, tomografia pozytronowo-emisyjna). Umożliwiły one obserwację mózgu w trakcie procesu uczenia się. Jedną z naturalnych konsekwencji rozwoju w/w był rozwój badań dotyczących związku procesów uczenia się z działaniem układu nerwowego.

W USA w 1981 roku po raz pierwszy J.L. O’Dell opublikował książkę „Neuroeducation: brain compatible learning strategies". Podkreślił w niej, że tylko zrozumienie neuronalnych mechanizmów procesów poznawczych pozwoli na zaprojektowanie efektywnych programów edukacji . W 1988 roku G. Preiss, profesor dydaktyki na Uniwersytecie we Fryburgu, specjalista w dziedzinie wczesnej edukacji matematycznej, rozpoczął badania wykorzystujące neurobiologiczne korelaty uczenia się. Wprowadził też pojęcie neurodydaktyki, uważając, że pedagogika szkoły i ogólnie dydaktyka musi pamiętać, że nauka polega na procesach mózgu i optymalizowanie/zmaksymalizowanie wyników poznawczych wymaga znajomości funkcjonowania układu nerwowego. Od tego czasu pojęcie neurodydaktyki zaczęło być przedmiotem dyskusji jako interfejs neurologii, dydaktyki, pedagogiki i psychologii (Tokuhama-Espinosa 2011).

Obecnie w literaturze przedmiotu do nazywania interdyscyplinarnych badań z zakresu edukacji oraz neuronauk używa się kilku pojęć:

- neuropsychologia edukacyjna - subdyscyplina psychologii, której twórcy jako pierwsi skupili się na badaniach mających na celu wyjaśnienie neuronalnego podłoża procesu uczenia się (Ruff i in. 2008);

- neurodydaktyka (Siegel 2001; Paloma, Fragnito 2013) lub neuropedagogika (Petlák 2012) - subdyscypliny stworzone przez pedagogów, którzy podkreślali konieczność znajomości funkcjonowania mózgu do budowania efektywnych programów edukacji;

- Mind, brain and education science (MBE) - najnowsze pojęcie, powstałe po interdyscyplinarnym spotkaniu w Delphi; odnosi się do dyscypliny integrującej na równi psychologię, pedagogikę i naueronauki (Samuels 2009; Fischer i in. 2007). 
W polskich publikacjach pojęć tych używa się zamiennie, co jest błędem. Analiza dostępnych publikacji zagranicznych oraz dorobku polskich pedagogów, m.in. B. Niemierki (Niemierko 2007), pozwala sformułować wniosek, że dyscyplina badająca neuronalne podłoże procesów edukacji (nauczania, wychowania i kształcenia) powinna być określana mianem neuropedagogiki.

Głównym założeniem neuropedagogiki jest organizowanie procesu edukacji w sposób uwzględniający neuronalne korelaty. Polem pracy nauczyciela jest mózg ucznia, ponieważ wszystkie nasze czynności mają mózgowe podłoże. Efektywność nauczania jest zatem uwarunkowana znajomością biologicznych czynników. Wśród najważniejszych szczegółowych założeń nowej subdyscypliny pedagogiki należy wymienić następujące:

- mózg jest kształtowany przez wszystko, co otacza człowieka oraz przez jego każdą czynność; wobec różnorodności w/w czynników budowa mózgu jest zatem indywidualna dla każdej osoby (inaczej będzie „uczył się” mózg osoby niemającej kontaktu z nowymi technologiami, a inaczej dziecka tzw. „cyfrowego tubylca”);

- wobec dużej ilości dostępnych współcześnie informacji, mózg dokonuje selekcji przyswajanego materiału w oparciu o subiektywna ocenę jego przydatności; ocena ta jest jednak zależna od procesu motywacji (przekonanie o użyteczności i bezpośredniej przydatności może być modyfikowane poprzez poziom motywacji), dlatego dla procesu edukacji kluczową zmianą powinno być położenie nacisku nie na modyfikację treści nauczania, ale kształcenia u nauczycieli i rodziców umiejętności właściwego motywowania dzieci i młodzieży;

- mózg jest organem społecznym - w sposób świadomy (starsze dzieci, młodzież i dorośli, czyli każdy kto ma umiejętność kierowania uwagi i jej utrzymywania) uczy się poprzez kontakt (personalny i z użyciem nowych technologii), w sposób nieświadomy i mimowolny (małe dzieci, część osób z zaburzeniami rozwojowymi) - wyłącznie poprzez kontakt personalny (neurony lustrzane nie uruchamiają się $\mathrm{w}$ trakcie kontaktu $\mathrm{z}$ ekranem);

- mózg uczy się powoli, a nieużywane neuronalne połączenia zanikają - efektywne zapamiętywanie wiadomości i umiejętności wiąże się z systematycznym powtarzaniem treści przez ucznia i nauczyciela oraz ze współpracą z rodzicami $\mathrm{w}$ formie pracy domowej;

- w mózgu nie ma obszaru odpowiedzialnego wyłącznie za jedną funkcję; każda czynność aktywuje wiele powiązanych ze sobą miejsc; im więcej z nich uczestniczy w procesie uczenia się, tym szybciej i efektywniej przyswajany jest materiał (nauczanie polisensoryczne);

- z wiekiem mózg zaczyna preferować niektóre sposoby edukacji (inteligencje wielorakie); 
- mózg jest plastyczny (ma możliwość rozwoju i regeneracji) przez cale życie człowieka, natężenie plastyczności jest jednak różne (tzw. okresy krytyczne) w różnym stopniu dla różnych części mózgu; zasadna jest zatem edukacja przez całe życie i podejmowanie terapii w różnych okresach rozwoju (nie zmienia to faktu, że najlepiej rokuje wczesna interwencja);

- stres musi być dozowany, ponieważ jego brak lub nadmiar blokuje proces uczenia się; ponadto nadmiar hormonów stresu niszczy komórki mózgu, wpływając w konsekwencji na ograniczenie funkcji warunkujących proces edukacji;

- koniecznym elementem skutecznej edukacji jest odpoczynek, który umożliwia regenerację komórek nerwowych oraz utrwalenie materiału (opracowano w oparciu o: Suárez-Orozco, Sattin-Bajaj 2010; Tokuhama-Espinosa 2010; Stein, Fischer 2011; Trníková, Petlák 2012, s. 43-51).

W świetle powyższego istotny jest również fakt, że w neuropedagogice nie chodzi o radykalne zmiany w zakresie treści programowych w edukacji, ale raczej o najbardziej efektywny rozwój zdolności poznawczych, które mogą być wykorzystywane w zakresie nabywania różnych obszarów treści (Ansari 2008). Kluczem do zmian we współczesnej szkole jest zatem modyfikacja nie tyle tego, czego uczymy w procesach wychowania czy nauczania, ale raczej wykorzystywanych metod.

\section{EDUKACJA ALTERNATYWNA A NEUROPEDAGOGIKA}

Progresywne i holistyczne modele od dawna postulowały dostosowanie do możliwości ludzkiego mózgu. Co ciekawe, jedna z pierwszych wzmianek o neuroedukacji pojawiła się w odniesieniu do edukacji holistycznej (Sonnier, Goldsmith 1985), a jeden z największych liderów w edukacji progresywnej, W. Jennings, z pomocą jednego z pierwszych neuroedukatorów, L. Hart, publikował przez prawie 10 lat cotygodniowy biuletyn o mózgu i edukacji (Carew, Magsamen 2010).

Biorąc pod uwagę powyższe rozważania, można przyjąć, że edukacja alternatywna i nauropedagogika mają wiele wspólnych założeń:

- ich początki związane są z krytyką tzw. szkoły tradycyjnej;

- obie proponują zmianę dotychczasowego sposobu organizacji edukacji poprzez dostosowanie jej do możliwości i graniczeń ucznia oraz postulowanie indywidualizacji nauczania i usytuowanie dziecka jako podmiotu, a nie przedmiotu $\mathrm{w}$ omawianym procesie;

- zakładają, że przyczyny niepowodzeń w nauce tkwią głównie w niewłaściwym organizowaniu procesu nauczania.

Edukacja alternatywna proponuje jednakże albo częściowe, albo całkowite zmiany w tradycyjnym systemie edukacji. Nowe rozwiązania przedstawiciele tego 
nurtu, opierają głównie na wynikach obserwacji dotychczasowych efektów działania szkół czy innych placówek oświatowych (tj. na wynikach badań pedagogicznych, uzupełnionych często o badania psychologiczne). Natomiast młodsza dyscyplina - neuropedagogika - postuluje raczej częściowe zmiany w istniejącym systemie, opierając nowe propozycje na badaniach interdyscyplinarnych z zakresu pedagogiki i neuronauk (często także uzupełnionych o badania z zakresu psychologii).

Wśród modeli, które integrują założenia obu tych dyscyplin, wymieniane są: szkoła alternatywna R. Steinera, M. Montessori, C. Freineta, szkoła jenajska P. Petersena, szkoła pracy J. Deweya, pedagogika waldorfska, metoda R. Emilia, metoda Carden, e-przedszkole, system szkolny Winnetki, metoda projektu W.H. Kilpatricka, metoda ośrodków zainteresowań O. Decroly’ego, system „mi-temps” M. Fourestiera, daltoński plan laboratoryjny, metoda projektu, szkoła Summerhill, pedagogika społeczno-personalistyczna Kamińskiego czy szkoła M. Grzegorzewskiej.

Analiza każdej z w/w pozwoliłaby uwidocznić świadome lub pośrednie odwołania do założeń obu porównywanych subdyscyplin. Najnowsze publikacje podkreślają jednak, że to neuropedagogika będzie wywierać największy wpływ na zmiany w systemie edukacji. Można zatem przypuszczać, że edukacja alternatywna będzie i powinna w przyszłości korzystać z dorobku i badań neuropedagogiki, by dokonywać ewaluacji efektów nowych propozycji rozwiązań edukacyjnych, lub by proponować nowe koncepcje. Możliwość weryfikacji hipotez pedagogicznych poprzez tzw. twarde badania jest bowiem nieocenionym i niezwykle wartościowym rozwiązaniem, które cieszy się coraz większą popularnością i uznaniem wśród naukowców.

\section{BIOBLIOGRAFIA}

Ansari D., 2008, Effects of development and enculturation on number representation in the brain. „Nature Reviews Neuroscience”, 9, 278-291.

Brinkmann B. (red.), 1974, Teorie der Schule - Sculmodelle, Kronberg.

Carew T.J., Magsamen S.H., 2010, Neuroscience and education: an ideal partnership for producing evidence-based solutions to Guide 21(st) Century Learning. „Neuron”, 67(5), 685-688.

Husén T., Postlethwaite N., 1985, Encyclopedia of Education. Oxford.

Fischer, K.W., Daniel D.B., Immordino-Yang M.H., Stern E., Battro A. Koizumi H. (red.), 2007, Why mind, brain, and education? Why now?. „Mind, Brain, and Education", 1(1), 1-2.

Kupisiewicz Cz., 2006, Podstawy dydaktyki. Warszawa. 
Kupisiewicz Cz., 2010, Szkice z dziejów dydaktyki. Białystok.

Kupisiewicz Cz., 2013, Szkoła alternatywna - definicje, rodzaje, ocena, perspektywy rozwoju. W: Melosik Z., Śiwerski B. (red.), Edukacja alternatywna w XXI wieku. Kraków.

Milerski P., Śliwerski B., 2000), Leksykon PWN „Pedagogika”. Warszawa.

Niemierko B., 2007, Kształcenie szkolne. Podręcznik skutecznej dydaktyki. Warszawa.

Paloma F.G., Fragnito V., 2013, The neuro didactic mind and body between pedagogy and neurosciences. „Research on Education and Media”, 2, 107-121.

Petlák E., 2012, Neuropedagogika i neurodydaktyka - tendencje XXI wieku. „Chowanna", 2, 59-66.

Ruff R.M., Iverson G.L., Barth J.T., Bush S.S., Broshek D.K., The NAN Policy and Planning Committee, 2008, Recommendations for diagnosing a mild traumatic brain injury: A National Academy of Neuropsychology education paper [pozyskano z: http://nanonline.org/docs/ResearchandPublications/Recommendations\%20 for $\% 20$ Diagnosing\%20a\%20MTBI\%20-\%20nan\%20education\%20paper.pdf] (dostęp: 13.03.2017)

Samuels B.M., 2009. Candifferencesbetweeneducation and neuroscience be overcome by mind, brain, and education?. „Mind, Brain, and Education”, 3(1), 45-53.

Suárez-Orozco M., Sattin-Bajaj C. (red.), 2010, Educating the whole child for the whole world. New York.

Siegel D. J., 2001, La menterelazionale. Neurobiologia dell'esperienza interpersonale. Milano, Raffaello Cortina.

Sonnier I.L., Goldsmith J., 1985, The Role of brain lateralization in learning and behavior modification. „Methods and Techniques of Holistic Education”, 11-16.

Stein Z., Fischer K.W., 2011, Directions for mind, brain, and education: Methods, models, and morality. „Educational Philosophy and Theory”, 43, 56-66.

Tokuhama-Espinosa T., 2010, Mind, brain, and education science. A comprehensive guide to the new brain-based teaching. W. W. Norton \& Company, Nowy Jork.

Tokuhama-Espinosa T., 2011, A brief history of the science of learning: Part 2 (1970spresent) [pozyskano $\mathrm{z}:$ http://education.jhu.edu/PD/newhorizons/Journals/Winter2011/Tokuhama5] (dostęp: 13.03.2017).

Trníková J., Petlák E., 2012, Neuroscience as a basis for innovations in education. „Acta Technologica Dubnicae", vol. 2, s. 43-51. 


\title{
NEUROPEDAGOGY AND ALTERNATIVE EDUCATION \\ IN THE $21^{\text {ST-CENTURY EDUCATION }}$
}

\begin{abstract}
The article attempts to outline the similarities and differences between neuropedagogy and alternative education - as concepts, which are the modern answer to the failure of the current education system. Praised by some, they are heavily criticized by others. For some, they are the ideal solution, which supports the development of children, for which there is no place in a traditional school, for others - a way of living the good life and a source of income. Regardless of the evaluation, it is worth taking a closer look at their sources, the proposed original solutions and the impact on the traditional system of education.
\end{abstract}

Keywords: neuropedagogy, alternative education, traditional school 